九州大学学術情報リポジトリ

Kyushu University Institutional Repository

\title{
Building Beneficial Roof Insulation in Vertical Housing : Physical and Economical Selection Method
}

Alam, Azimil Gani

National Housing \& Urban Development Corporation (Perumnas)

Nasrudd in

Faculty of Engineering, University of Indonesia

Tirta, Andy

Faculty of Engineering, Sumbawa University of Technology

Priambada, C. Kurniawan

National Housing \& Urban Development Corporation (Perumnas)

https://doi.org/10.5109/2321006

出版情報：Evergreen. 6 (2)，pp.124-133，2019-06. 九州大学グリーンテクノロジー研究教育センター バージョン：

権利関係 : 


\title{
Building Beneficial Roof Insulation in Vertical Housing: Physical and Economical Selection Method
}

\author{
Azimil Gani Alam ${ }^{1,3,},{ }^{*}$, Nasruddin ${ }^{2,}$ Andy Tirta ${ }^{3,}$ \\ C. Kurniawan Priambada ${ }^{1}$ \\ ${ }^{1}$ National Housing \& Urban Development Corporation (Perumnas), Indonesia \\ ${ }^{2}$ Faculty of Engineering, University of Indonesia \\ ${ }^{3}$ Faculty of Engineering, Sumbawa University of Technology, Indonesia
}

*Corresponding Author E-mail: ganiazimil@gmail.com

(Received February 18, 2019; accepted March 26, 2019)

\begin{abstract}
Indonesian government is accelerating the development of national housing through its stateowned company, in which all planning designs have been already established including urban design and urban revitalization. But unfortunately the detailed engineering of installation building, especially roof insulation building has not gotten much attention yet. Main contractor was paid for the project but the insulation should be an extra work to be paid due to its status as variant order. So, any kind of insulation types are pleased to be proposed. This paper proposed Material and CostBased methods that was studied by comparing three proposed materials from physics and economic point of view with its theory and simulation data whereas computer simulation also conducted. Evidently, insulation has an important role to be installed due to gaining solar heat reduction from solar exposure through the rooftop based on indoor thermal condition and energy of cooling utilities. Besides, those methods presented the simplified decision for company to select a beneficial material to be installed.
\end{abstract}

Keywords: Roof Insulation, Outdoor Air Temperature, Thermal Transfer

\section{Introduction}

Indonesia as new emerging developing country is running several physical development programs nowadays, where almost all designs of infrastructure project has been done at previous president's era. In housing field, government is accelerating a million houses project that should be finished in $2019^{1}$. Practically, government is not only running landed housing but also vertical housing project at most of Indonesian urban city. Through the stateowned company in specialty of housing (PERUMNAS), government is accelerating the realization number of vertical housing with various model and mechanism ${ }^{2}$. However, it is gradually found that there is incomplete particular design at drawing's planning, especially on building field utilities in those projects.

Clearly known that Indonesia has tropical climate which conducts high cooling load from sun-exposure and ambient temperature, and there are relation between the interface form and the thermal comfort which is influenced by radiant mean temperature of the roof ${ }^{3}$. Thus, natural air comfortability probably decreased as a cause of solar heat gain. So, occupants need air-conditioning system in their houses, which conduct high energy consumption for air conditioning purposes ${ }^{4}$.

Thermal insulation as physical component for building is commonly known as important part which is installed on building's rooftop and facade to reduce solar heat gain through building roof that could rise indoor temperature above ambient ${ }^{5,6}$. Other than that, building roof insulation conducts room energy for saving value on the top floor while electricity demands of indoor cooling consumes lower energy by applying insulation ${ }^{7,8}$. There are several application to reduce external heat gain, such as cool roof $(89-90 \%)$, green roof $(32-41 \%)$ and insulation $(62-72 \%)^{9}$. On the other side, the utilization of insulation was successfully reduced surface temperatures of roof and slab by performing internal air temperatures decrease in tropical country ${ }^{10,11}$. Compare to those materials and systems, roof insulation is widely known and popularly adopted by prescribes $\mathrm{U}$-value for roofs in considering the impact of energy efficiency ${ }^{12,13}$. Beside, payback of initial cost from insulation by life-cycle analysis showed the possibility of insulation using ${ }^{14}$. As the aid of study, building energy modeling and numerical analysis can also present the performance of energy saving by varying the 
roofs within insulation even in tropical climate places ${ }^{15,16}$. Other than that, the alternative way is whitening the roof, so it can bring the effect in reducing the indoor air temperatures in building ${ }^{17}$. As a review, insulation and paint are common interactive solution to reduce the cooling load of the building as an effort of decreasing energy demand of the building ${ }^{18}$.

Distraction of economical present output to establish the cheaper housing, PERUMNAS may be able to consider the price of insulation to continue the decision of application in construction process. This paper proposes the applicative method on how material selection concerning the energy performance and initial cost by applying energy simulation, cost and decision analysis.

Thus, main contribution of this paper is to introduce the method of material selection for application at construction field by reviewing each material sample from physic and economic aspect in combined with simulation as tool. In addition, this paper is expected could be a consideration for researcher and material inventor in developing suitable roof insulation from economy aspects in order to be more applicable and suitable in market and society.

\section{Theory}

Building physics is being developed by researchers, academician and practitioners started from early $20^{\text {th }}$ century. In line with skyscrapers building growth number, people keep learning things related to building materials, ventilation, air thermal and condition, acoustics, protection against disasters, energy consumption in buildings and studying physical phenomena that take place in buildings such as thermal phenomena, fire, energy, etc ${ }^{19}$. However, calculation of the analysis of building thermal phenomena can be done by computer-based simulation or numerically with this following Eq. 1.

$$
R T T V=\frac{\alpha\left(A_{r} \cdot U_{r} \cdot T D_{E K}\right)}{A_{0}}
$$

The equation above is known as the Roof Thermal Transfer Value (RTTV) or the value of the heat propagating through the roof ${ }^{20}$. Fully noted that there is no glazing roof surface in common Indonesian high rise housing, so the equation could be simplified as above, where :

$$
\begin{array}{lll}
- & R T T V & : \text { Roof Thermal Transfer Value }\left(\mathrm{W} / \mathrm{m}^{2}\right) \\
- & \alpha & \text { : coefficient of surface }
\end{array}
$$

$$
\begin{array}{lll}
- & A_{r} & \text { : roof area }\left(\mathrm{m}^{2}\right) \\
- & A_{0} & \text { : total roof area }\left(\mathrm{m}^{2}\right) \\
- & U_{r} & \text { : roof thermal transmittance }\left(\mathrm{W} / \mathrm{m} \cdot{ }^{0} \mathrm{C}\right) \\
- & T_{D E K} & \text { : temperature difference }\left({ }^{0} \mathrm{C}\right)
\end{array}
$$

Despite the fact that those values vary in different time and weather, this formula states the range of possible thermal transfer value from room's outdoor conditions with some assumptions and data. Different from dimensional numerical calculations, computer - based simulation calculations emphasize on the dynamics of the room condition directly. Thus, Building Energy Simulation still a priority method to be conducted as a numerical iteration by obtaining energy consumption of the building with real input, such as building parameters and weather condition dynamically.

In Indonesia, it is commonly known that insulation material is applied as building's construction components such as glass wool, rock wool, and polyurethane, otherwise the roof could only be painted with paintcoating. Glass wool usually characterized as low thermal conductivity and density. The same as glass wool, material properties of rock wool are also similar except its high density and soundproof ability. Compare to rock wool and glass wool in similar thickness, polyurethane has lower thermal conductivity and its easiness of installation than other insulations on the construction process. Generally, common designs have a shortcut way by directly covering the roof with the paint, if the building does not want to be insulated. Certainly, liquor paint should have lighter color to reduce the alpha $(\alpha)$ in Eq. 1 so that RTTV decreases linearly ${ }^{20}$. Still, paint coating commonly could help the roof from any leaks of roof concrete if using waterproof paint.

Referring to code of standard ${ }^{20}$, all of any surfaces always have $\alpha$-value for RTTV calculation. Concrete, which has grey color with $\alpha$-value, standardized of 0.71 , where roof concrete with any insulation covered below. In this paper, paint coating was assumed using light-grey color as defined in shop drawing, with $\alpha$-value of 0.30 . Practically, in building construction while in designing phase-work, roof insulation material is determined only based on thickness of insulation in accordance with the brochure / material information obtained. Table 1 provides matrix and physical properties data for each discussed materials. Noted that aluminum foil is only a supporting installation component aimed for rock wool and glass wool below the roof and its effect of insulation is neglected.

Table 1 : Matrix and physical properties data of discussed materials.

\begin{tabular}{|l|c|c|c|c|c|c|c|}
\hline \multicolumn{7}{|c|}{ Material Thermal \& Physical Properties } \\
\hline Subject & (unit) & Concrete & Glass wool $^{\mathbf{2 3}}$ & Rock wool $^{\mathbf{2 3}}$ & PU $^{\mathbf{2 1} 22,23}$ & Paint & Aluminium foil \\
\hline Conductivity & $\mathrm{W} / \mathrm{m}^{\circ} \mathrm{C}$ & 1.95 & 0.049 & 0.039 & 0.022 & 0.18 & 235 \\
\hline Density & $\mathrm{Kg} / \mathrm{m}^{3}$ & 2,200 & 13 & 60 & 64 & 1,300 & 2,700 \\
\hline Thickness & $m m$ & 200 & 50 & 50 & 5 & 0.5 & 0.30 \\
\hline$\alpha$ & - & 0.71 & - & - & - & 0.30 & - \\
\hline
\end{tabular}


If external heat gain were transferred successfully through any obstruction or envelope building, it will enter the room through envelope building and gain any temperature objects inside, including air, liquid or solid form depends on their specific heat value and mass following the theoretical formula in Eq. 2.

$$
Q=m . c . \Delta T
$$

Whereas:

$$
\begin{array}{lll}
- & m & : \text { Mass of object }(\mathrm{kg}) \\
- & c & : \text { Specific heat }\left(\mathrm{J} / \mathrm{Kg} .{ }^{\circ} \mathrm{C}\right) \\
- & \Delta T & : \text { Temperature difference }\left({ }^{\circ} \mathrm{C}\right)
\end{array}
$$

Side by side with numerical calculations, simulation studies need to be included in this study. In this paper, computer simulations will use open-source software namely EnergyPlus v8.40 from New Renewable Advance Laboratories, of Department of Energy, $\mathrm{USA}^{24}$. Computer simulations can calculate all the dynamics of physical phenomena by analyzing each inputted variable simultaneously to be calculated in a time series that correlated each other. Any equation and calculation formula in EnergyPlus software are referred to all applicable standards, include American Society of Heating Refrigeration and Air-Conditioning Engineers (ASHRAE).

\section{Scope and Methodology}

This study involved a literature review on thermal transfer values caused by external radiant heat (sun) which formed complex in weather data. In addition to material characteristic based on their properties, the construction's schedules and each price of installation are correlated consideration. Of course, the dis-communication between the building plan's consultant and the building's owner about the price and material thickness of roof construction becomes main focus of analysis beside both of them are seldom to consider the thermal resistance or thermal conductivity from their designs. Later on, objects of consideration are divided into two kinds, they are roof insulation construction's schedules with similar cost (costbased) and roof insulation construction's schedules with similar thickness (material-based), and RTTV by those schedules have to be calculated. In regard to literature, thermal transfer occurs due to several parameters in the building. Thus, this research conducted calculation by two-way, they are simulation and numerical calculation by using those parameters.

By numerical calculation, thermal transfer value of sun exposed to the envelope building will be an output. For supporting analysis, computer simulation for building physics performance will be applied to those construction scenarios in order to know the room temperature dynamically in addition to its cooling energy demands. To generalize the cooling unit condition, the Coefficient of Performance (COP) of cooling equipment is 3.00 by assuming it is commonly in general market conditions, on same value of room set temperature on $25^{\circ} \mathrm{C}$, referring to room-health level standard ${ }^{25}$. As a supporting output, the cooling load conducts as an impact of sun exposure through the envelope building. Cooling load value is description of how the rooms need minimum capacity of cooling unit and their energy consumption for external heat gain only. Figure 1 shows how systematic explanation of this writing works.

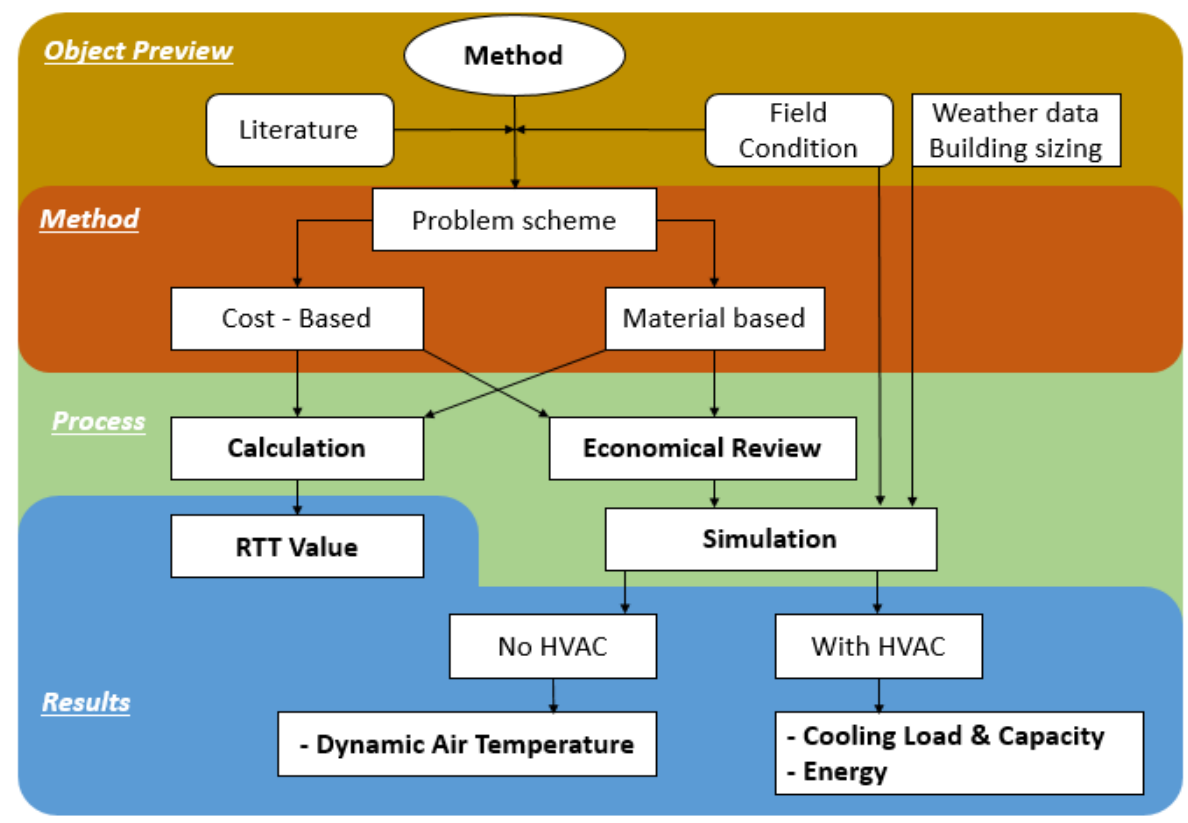

Fig. 1 : Flowchart of work methodology 
The object of simulation and calculation was the selected high-rise vertical housing, 20 stories building typically from bottom to upper floor in Medan city, Indonesia, and it is developed by PERUMNAS. This work selected the simplest dwelling apartment in single with 36 $\mathrm{m}^{2}$ net-area as sample for calculation with its façade orientation to west, the highest probability of sunexposure which could represent another as maximum possible value of cooling capacity needed later on. This room is located on top floor, so the roofs were exposed by sun directly. The simulation used weather data in April 2018 where the sun is vertically bright on human head precisely. However, based on weather data, April and September are the time with the highest solar heat gained in Medan city. Figure 2 shows the envelope situation of building through building modeling in EnergyPlus software, so the rooms beside the room sample was neglected variable in this writing. Figure 3 shows the floor plan of selected room for this work.
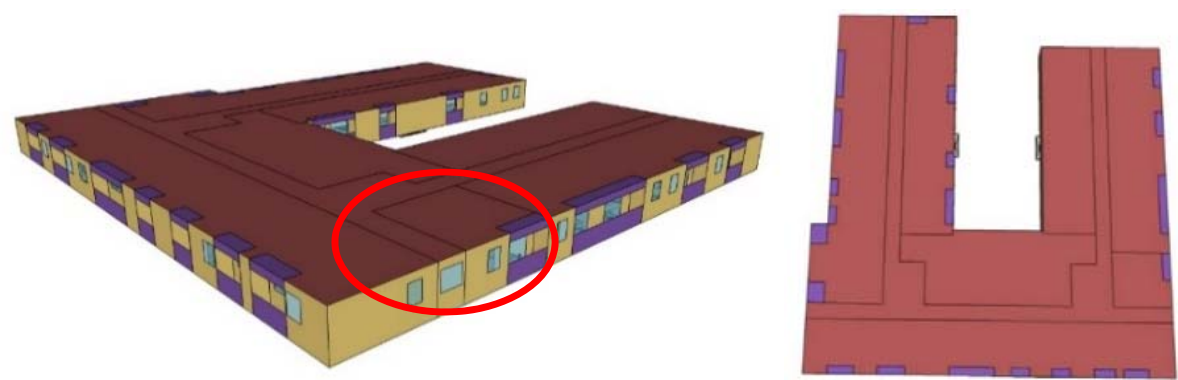

Fig. 2 : Rooftop part of building view from above and diagonally (Sketch-up drawing)

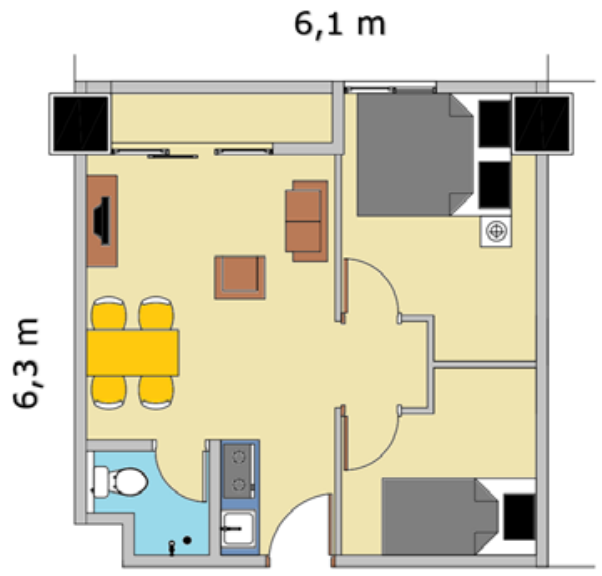

Fig. 3 : floor-plan of room sample on top floor (Architectural Drawing)

This work conducted some different scenarios by varying the construction schedule and different material in each layers as shown in Table 2. Scenario 1 is the example where roof was made without any insulation and coating. Scenario-2, 3 and 4 were proposed as various concrete ceiling models by applying few different insulation with glass wool, rock wool and polyurethane. Besides, Scenario-5 was designed as an example where the roof was coated by paint without any insulation on the bottom side. Material-based as shown in figure 1, are scenario of construction schedules as shown in table 2 with similar thickness of glass wool, rock wool and polyurethane.

Of course, construction cost in each scenario is different due to characteristic of insulation prices. This design was conducted to show the characteristic of impact in room's temperature situation. Clearly shown on table 3 that glass wool is cheaper than rock wool and polyurethane is the most expensive of all sampled materials in this paper. However, scenario-5 is exceptional since it has no insulation on its layer.

Table 2 : Construction scenarios with different insulation material using (material based).

\begin{tabular}{|c|c|c|c|c|c|}
\hline Construction schedules \# & 1 & 2 & 3 & 4 & 5 \\
\hline Top layer & $\begin{array}{l}\text { Heavyweight } \\
\text { Concrete }\end{array}$ & $\begin{array}{l}\text { Heavyweight } \\
\text { Concrete }\end{array}$ & $\begin{array}{l}\text { Heavyweight } \\
\text { Concrete }\end{array}$ & $\begin{array}{l}\text { Heavyweight } \\
\text { Concrete }\end{array}$ & $\begin{array}{l}\text { Waterproof } \\
\text { painting }\end{array}$ \\
\hline $2^{\text {nd }}$ layer & & Glasswool & Rockwool & Polyurethane & $\begin{array}{l}\text { Heavyweight } \\
\text { Concrete }\end{array}$ \\
\hline $3^{\text {rd }}$ layer & & Alumunium foil & Alumunium foil & & \\
\hline
\end{tabular}


Furthermore, cost-based as shown in figure 1, are a scenarios of construction schedules like described on table 2 with similar construction cost, so on the matrix of comparison of material needs and prices data are shown on table 4. This method was conducted to describe performance of insulation with similar cost, so that the building's owner is able to consider the selection economically.

For realistic approach, weather data was formed where dry-bulb temperature $\left({ }^{\circ} \mathrm{C}\right)$, relative humidity $(\%)$, and sun glare exposure $\left(\mathrm{W} / \mathrm{m}^{2}\right)$ were included. Simulation was conducted with sized building in determined times period. By those variables, simulation outputs were expected to show room temperature dynamically with its electricity consumption from cooling unit. In addition, all data on table 3 and 4 were analyzed by using data survey from quantity surveyor's consultant which was in charge of responsibility for this project. All prices were surveyed in local currency where foreign exchange condition at that time was 1 US Dollar was equivalent to 14,000 Indonesian Rupiah.

Table 3 : installation price analysis for material based (thickness similarity on $50 \mathrm{~mm}$ )

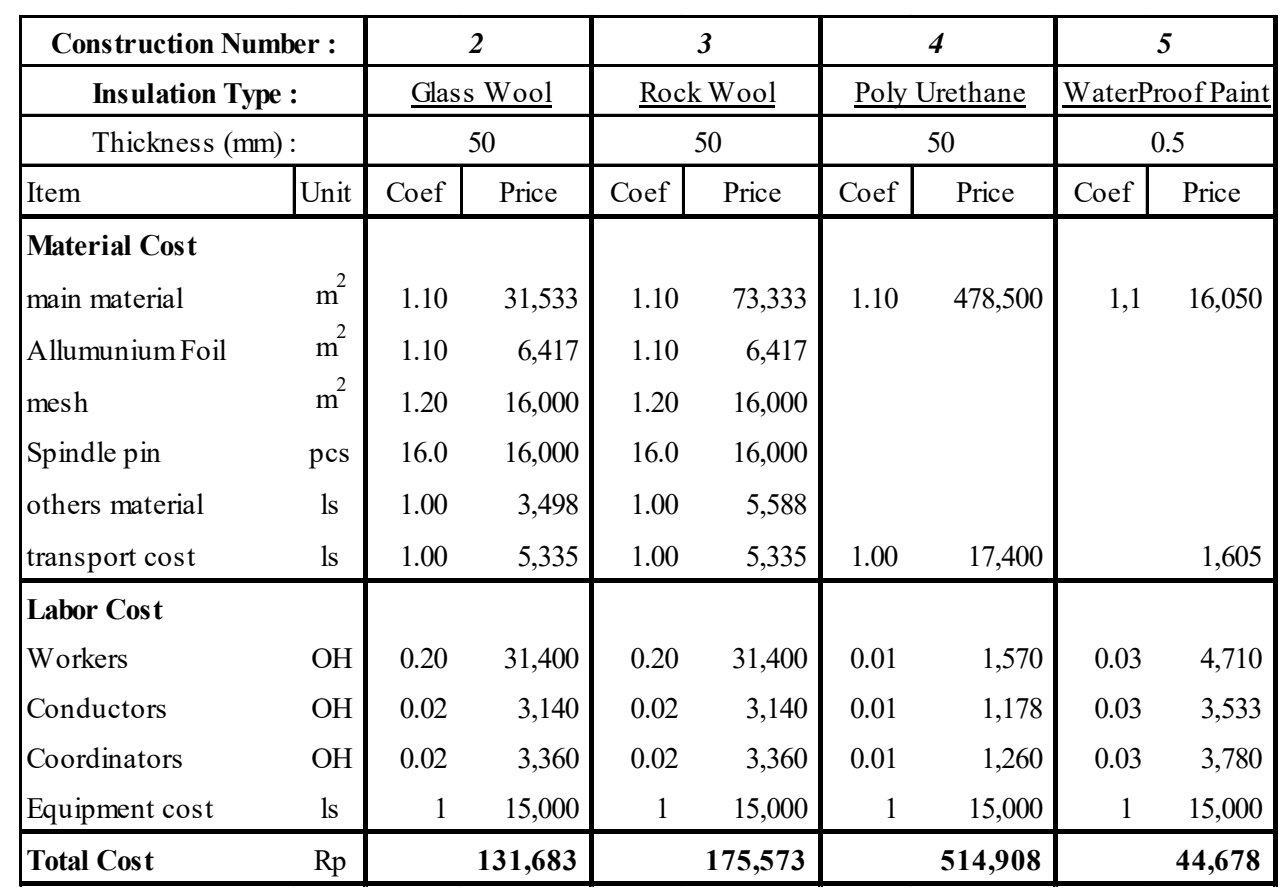

Table 4 : installation price analysis for cost-based (price similarity $\pm \mathrm{Rp} 175.000 / \mathrm{m}^{2}$ )

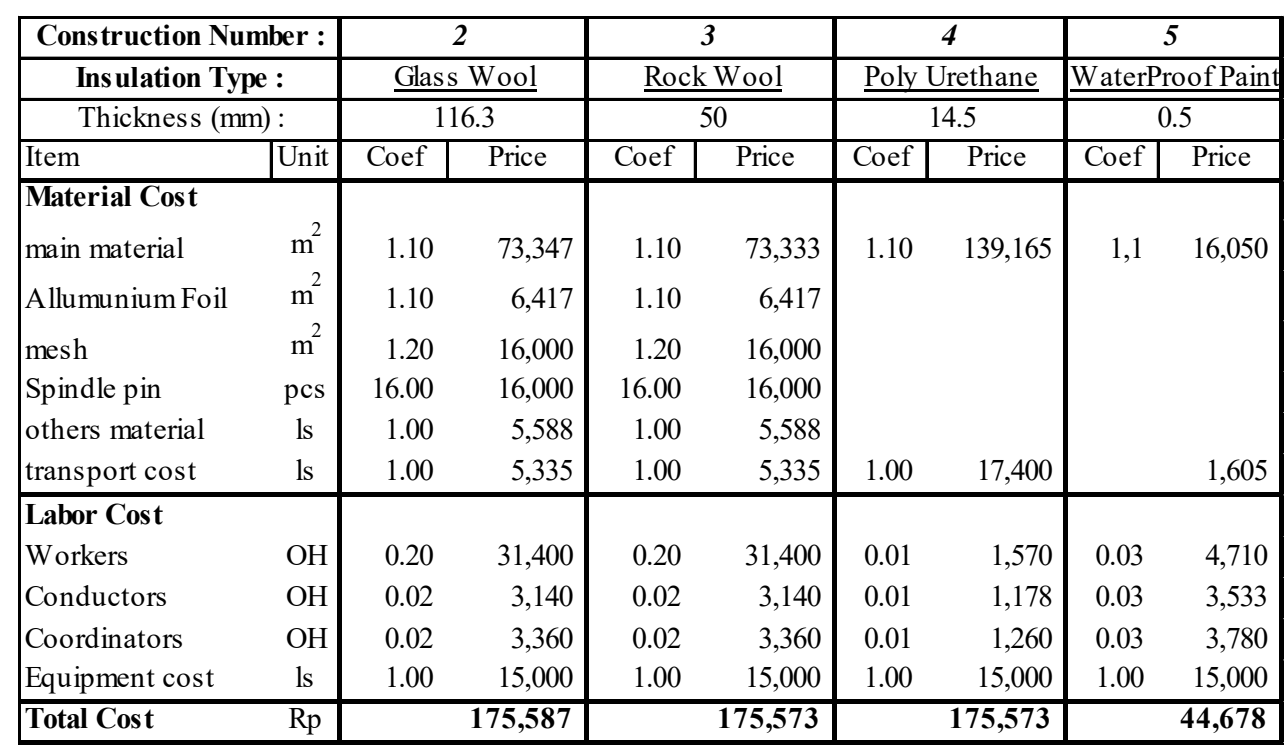




\section{Result and Discussions}

Calculation and computer simulation was conducted to investigate the effect of insulations, while numerical calculation was conducted to identify the insulation capabilities quantitatively with computer simulation showed simulative impact with varies data and graphs.

\subsection{Numerical}

Numerical calculation was conducted by following the equation 1 within the results of RTTV that has been shown in table 5, shown in varies values due to thickness and type of material in each construction schedules and methods. RTTV of each construction schedules is needed to be compared with construction schedule $1\left(34.1 \mathrm{~W} / \mathrm{m}^{2}\right)$ as the baseline value whereas its layer has no insulation applied. Thus the comparison means the effectiveness of insulation applications either material-based construction or costbased construction methods. Certainly, the lowest RTTV is the worst heat insulation while the highest RTTV is the best heat insulation, beside its benefit about comfortability of indoor temperature.

In regard to material-based with similarity of material thickness, Polyurethane showed the best performance of heat insulation empirically than other materials. However, rock wool and glass wool showed similar performance in case of RTTV results. Instead of insulation application, paint coating showed significance effect compared to construction schedule 1 (with no insulation).

Table 5 : Results of RTTV by all schedules and methods.

\begin{tabular}{|c|c|c|}
\hline Construction & \multicolumn{2}{|c|}{$\boldsymbol{R T T V}\left(\boldsymbol{W} / \mathbf{m}^{2}\right)$ with Method of : } \\
\cline { 2 - 3 } Schedules : & Cost Based & Material Based \\
\hline $\mathbf{1}$ & - & 34.1 \\
\hline $\mathbf{2}$ & $\mathbf{1 . 4 1}$ & 3.12 \\
\hline $\mathbf{3}$ & $\mathbf{2 . 5 3}$ & $\mathbf{2 . 5 3}$ \\
\hline $\mathbf{4}$ & 4.23 & $\mathbf{1 . 3 4}$ \\
\hline $\mathbf{5}$ & \multicolumn{2}{|c|}{10.0} \\
\hline
\end{tabular}

In case of cost-based, result variations were different with material-based, where RTTV results represented the glass wool was the best among rock wool and polyurethane. For sure, it was noted that cost-based constructions were formed with limitation of construction's cost which less than 175,000 Indonesian Rupiah and glass wool was the cheapest material in this discussion following table 3 in comparing those material with similar thickness and wide. However, material's thicknesses were designed to have similar price for this cost-based methods, so that the thickness would be different. This RTTV results offer different viewpoint when designing material thickness that concerning its material properties. For dynamic results about room's air temperature, simulation was conducted with several inputted data.

\subsection{Simulation}

This computer simulation was conducted by using EnergyPlus V8.40 with Google Sketch-Up as add-ons intending to define the building dimension. Simulations were conducted for all construction methods and construction schedules which were designed into 2 kind of setting : without HVAC and with HVAC systems. The setting of without-HVAC was designed to study the room temperature effect of those construction models dynamically, while the setting of with-HVAC system was designed to study the cooling load of room to meet the standard temperature degree in terms of room's comfort quality $\left(25^{\circ} \mathrm{C}\right)$. The simulation results of setting of noHVAC were described graphically in figure 4.

Results showed that the temperature series similarly increase each other, following the solar radiation which in line with the time. It means that there is trapped-heat inside the room after the external heat gain exposed through the roof and façades ${ }^{26}$, where the insulation could impede the building's heat release ${ }^{9}$. Later on, solar radiation which exposed through the wall was trapped inside and then gaining the room temperature. Instead of temperature increases, outdoor air temperature (OAT) is lower than room temperature in all simulation results. All graphics showed the delay between peak-point of room temperature at 16:00 with peak of OAT at 14:00. This phenomenon is similar with statement of delay between outdoor and indoor temperature instead of material properties of envelopes building.

Graphs in figure 4 showed the difference between each temperature where main focus is temperature differences between construction schedule-1 compared to OAT as a baseline $\left(R M T_{X}\right)$, so on their other scenarios, a proof of solar heat resistance by insulation application against solar heat gain. However, there are 2 (two) temperature differences in the same time where the phenomena of trapped-heat happened, they are baseline temperature difference between construction schedule 1 vs. OAT $(\Delta \alpha)$, and temperature difference between insulated roof vs. OAT $(\Delta \beta)$. The difference between $\Delta \alpha$ and $\Delta \beta$ yields the new equation called Heat Resistance Effectiveness in percentage value as proposed calculation of material evaluation in this discussion. The mathematic model is described by equation 3 .

$\operatorname{HRE}(\%)=1-\frac{\Delta \beta}{\Delta \alpha}=1-\frac{\left(R M T_{x}-O A T\right)}{\left(R M T_{b}-O A T\right)}$

Where:

- HRE : Heat Resistance Effectiveness (\%)

- $R M T_{X}$ : Room Mean Temperature by applying ' $\mathrm{X}$ ' insulation $\left({ }^{\circ} \mathrm{C}\right)$

- $R M T_{b}:$ Room Mean Temperature without insulation $\left({ }^{0} \mathrm{C}\right)$

- OAT : Outdoor Air Temperature $\left({ }^{0} \mathrm{C}\right)$

Therefore, HRE value (\%) represents the performance number of insulation at each materials in resisting heat gain through envelopes followed by varies time series. HRE values are presented in figure 5. However, HRE values are observed with exception that the room has no cooling unit, so the room is heated naturally. 

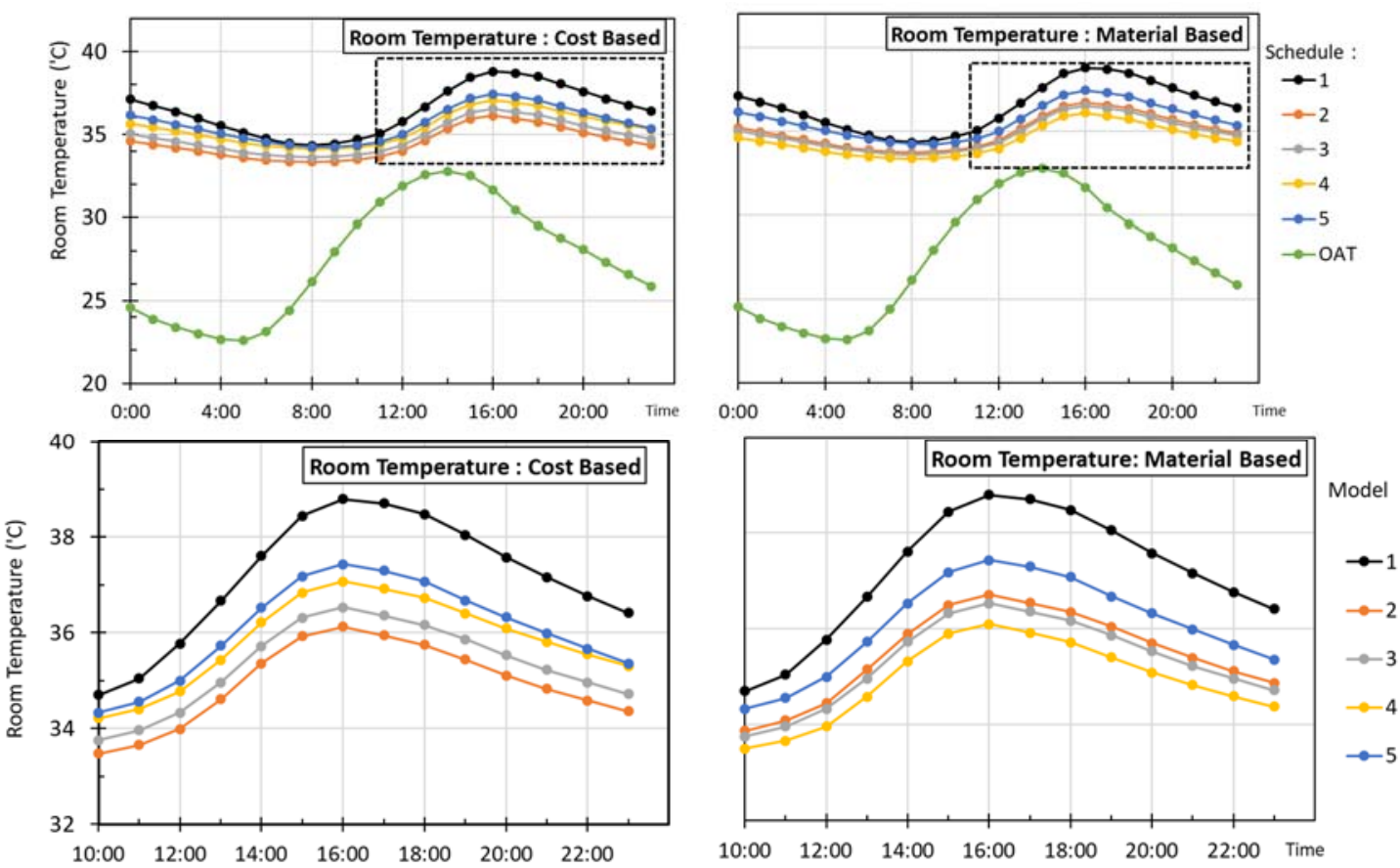

Fig. 4 : Room Temperature Conditions (left - Cost Based ; right - Material based)
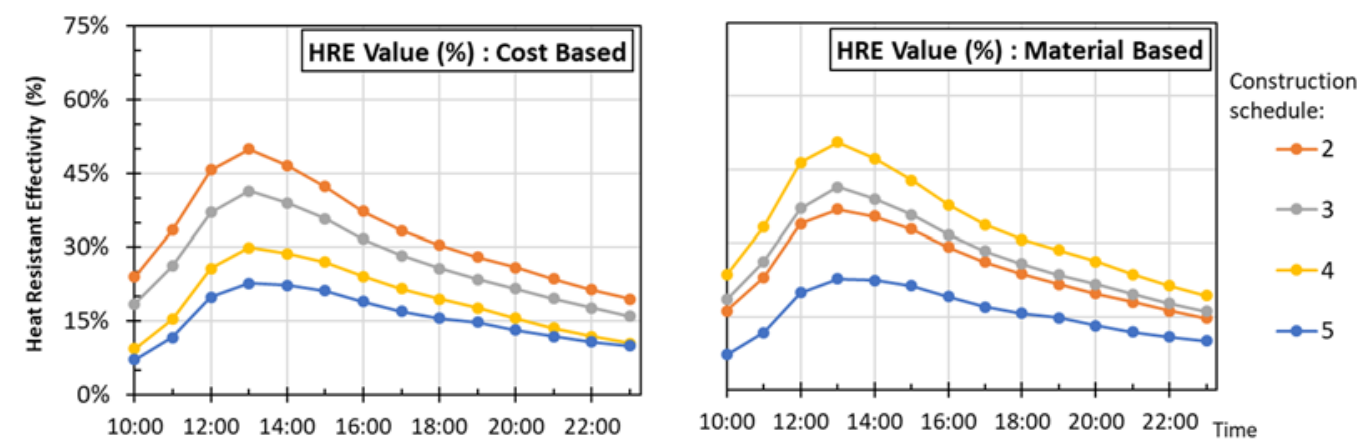

Fig. 5 : Insulation characteristic of HRE vs. time series. (Left - Cost Based ; Right - Material Based )

HRE value reached highest point while applying polyurethane (construction schedule -4) in case of same thickness on all insulation materials that followed by HRE values of rock wool and glass wool insulation with a little difference. It is clear enough that rock wool and glass wool insulation have similar effectiveness instead of those nonthermal properties or economic side point. Design of highrise building is recommended to consider for a better insulation, in regard to material with high HRE value. However, any consideration from building's owner perspective to spend the construction cost may be different due to purchasing power on price of insulation.

Of course this perspective is determined by the similarity of thickness from those materials where the building designers are assumed that they have little consideration in thermal properties scientifically at all kind of insulation materials. Building designer may consider the price of each material, so the building owner may approve the selected construction design by number of total cost. Thus, cost-based schedule was conducted through computer simulation to show different perspective about HRE in similar cost at each material with size or thickness of area varied.

Regarding figure 5 for HRE of cost-based, glass wool material has the highest effectiveness up to $25-50 \%$ followed by rock wool material of $18-45 \%$ and polyurethane of $10-30 \%$. However, effectiveness on those materials is significantly different. In addition, results of construction schedule -5 of material-based methods also can be compared with cost-based results that paint coating is alternative way and not significantly different with result of $5-20 \%$. 
Table 6. Energy consumption and effectivity cost on each scenarios.

\begin{tabular}{|c|c|c|c|c|c|c|c|c|c|c|}
\hline \multicolumn{2}{|c|}{ Simulation of : } & \multirow{2}{*}{\multicolumn{5}{|c|}{$\frac{\text { Material Based }}{\text { Construction Schedule : }}$}} & \multirow{2}{*}{\multicolumn{4}{|c|}{$\frac{\text { Cost Based }}{\text { Cons truction Schedule: }}$}} \\
\hline \multirow{2}{*}{ Subject } & \multirow{2}{*}{ Unit } & & & & & & & & & \\
\hline & & 1 & 2 & 3 & 4 & 5 & 2 & 3 & 4 & 5 \\
\hline \multirow{3}{*}{$\begin{array}{l}\text { Minimum } \\
\text { Capacity }\end{array}$} & Watt & 3,865 & 2,361 & 2,296 & 2,129 & 3,273 & 2,116 & 2,296 & 2,550 & 3,273 \\
\hline & $B T U / h$ & 13,188 & 8,057 & 7,834 & 7,263 & 11,169 & 7,221 & 7,834 & 8,701 & 11,169 \\
\hline & $H P$ & 1.72 & 1.05 & 1.02 & 0.95 & 1.45 & 0.94 & 1.02 & 1.13 & 1.45 \\
\hline \multirow{2}{*}{\begin{tabular}{|c|} 
Monthly \\
Energy \\
Consumption \\
\end{tabular}} & $k W h$ & 282.3 & 177.9 & 172.0 & 158.4 & 238.5 & 156.9 & 172.0 & 195.1 & 238.5 \\
\hline & $\begin{array}{c}\text { Saving } \\
\text { potential }\end{array}$ & & $37 \%$ & $39 \%$ & $44 \%$ & $16 \%$ & $44 \%$ & $39 \%$ & $31 \%$ & $16 \%$ \\
\hline \multirow{2}{*}{$\begin{array}{c}\text { efectivity } \\
\text { cost }\end{array}$} & $R p / m^{2}$ & & 131,683 & 175,573 & 514,908 & 44,678 & 175,587 & 175,573 & 175,573 & 44,678 \\
\hline & $R p /\left(m^{2} . \%\right)$ & & 3,563 & 4,496 & 11,733 & 2,878 & 3,953 & 4,496 & 5,688 & 2,878 \\
\hline Material & & & glass wool & rock wool & $\begin{array}{c}\text { Poly } \\
\text { Urethane }\end{array}$ & Roof Paint & glass wool & rock wool & $\begin{array}{c}\text { Poly } \\
\text { Urethane }\end{array}$ & Roof Paint \\
\hline thickness & $\mathrm{mm}$ & & 50 & 50 & 50 & 0.5 & 116 & 50 & 14.5 & 0.5 \\
\hline
\end{tabular}

\subsection{Economic View}

In addition to HRE values, insulation materials could be reviewed in terms of economic point of view by using computer simulation results. Here, economic point of view was seen through the amount of utilized energy on each construction schedule where the baseline of energy consumption is appointed on construction schedule-1.

Following the equation 2, the temperature is straightly proportional to energy or external heat gain through façade, so that $\Delta T$ between indoor obstacle temperature and temperature set point of cooling unit (Air-Conditioning) is the function of cooling load for the indoor evaporator from cooling unit system. On the other hand, use energy efficiency by comparing energy consumption with the appointed baseline and calculate it. Dealing with the construction cost $\left(\mathrm{Rp} / \mathrm{m}^{2}\right)$, cost effectiveness is calculated with construction cost divided by energy efficiency. Thus, cost effectiveness here represents how much investment needed to contribute to the energy saving for each percentage. However, the lowest effectiveness cost may be the best choice as cheapest selection but it does not mean the maximum potential of efficiency. This concept is the main statement of this writing to analyze economic point of view.

In regard to construction schedule-1 from materialbased construction as the baseline, construction schedule4 (polyurethane) hold the highest efficiency, followed similarly by rock wool $(39 \%)$ and glass wool $(37 \%)$. However, the lowest cost effectiveness from materialbased construction with insulation application is preferred on glass wool materials (construction schedule -2) with $\mathrm{Rp}$ $3,563 /\left(\mathrm{m}^{2} . \%\right)$. Besides, paint coating (construction schedule-5) is alternative solution regarding to the cost effectivity and total cost instead of its slightly higher energy consumption.

Comparing the results of cost-based construction on Table 6, glass wool (construction schedule -2 ) reached the highest efficiency with the lowest cost effectiveness, compared to rock wool or polyurethane insulation. Certainly, the thickness of cost-based and material-based is different, where glass wool in cost-based construction $(116 \mathrm{~mm})$ is thicker than glass wool in material-based construction. Other than that, polyurethane thickness of cost-based construction $(14.5 \mathrm{~mm})$ is thinner than polyurethane in material-based $(50 \mathrm{~mm})$, so that rock wool thickness on both construction schedules following Table 3 and 4. At least, glass wool is the most preferable to be chosen as the effective and the cheapest material for highrise vertical housing regarding table 6 .

\section{Conclusions}

The method of study in material selection towards effectiveness of indoor thermal insulation was introduced with few approach in comparing the heat resistance and effectiveness where computer simulation and literal calculation are within. In addition, various formation of material layer design regarding similarity of cost and thickness conducted as variables to provide multi point of views, so the analysis could be defined more complex.

Polyurethane that used for insulation was proven in simulation that it is the most effective among other materials where the thickness was set similar. Beside, polyurethane is commonly known as the easiest material to be installed and maintained, and it is different with wool material that needs wire-mesh with foil to wrap. Otherwise, polyurethane is recommended only for high-end level of housing which has high-price limit.

In term of cost, glass wool has preferable offers referring to the results of cost effectiveness, it is commonly known as cheaper material of insulation. Beside cost effectiveness, glass wool is also preferable in regard to results of simulation with similarity of material thickness. For low-end vertical housing, it is possible to not installing insulation but paint coating that low-cost design for the roof as alternative recommendation, in addition to its benefits to protect the roof from any rain-leakage. 
Table 7 : Decision Analysis

\begin{tabular}{|c|c|c|c|c|c|c|c|c|c|c|}
\hline \multirow{4}{*}{ Criteria } & \multirow{4}{*}{ Score } & 1 & \multicolumn{2}{|c|}{2} & \multicolumn{2}{|c|}{3} & \multicolumn{2}{|c|}{4} & \multicolumn{2}{|c|}{5} \\
\hline & & \multirow{3}{*}{$\begin{array}{c}\text { Heavyweight } \\
\text { Concrete }\end{array}$} & \multicolumn{2}{|c|}{$\begin{array}{l}\text { Heavyweight } \\
\text { Concrete }\end{array}$} & \multicolumn{2}{|c|}{$\begin{array}{c}\text { Heavyweight } \\
\text { Concrete }\end{array}$} & \multicolumn{2}{|c|}{$\begin{array}{l}\text { Heavyweight } \\
\text { Concrete }\end{array}$} & \multicolumn{2}{|c|}{ Waterproof painting } \\
\hline & & & \multicolumn{2}{|c|}{ Glasswool } & \multicolumn{2}{|c|}{ Rockwool } & \multirow{2}{*}{\multicolumn{2}{|c|}{ Polyurethane }} & \multirow{2}{*}{\multicolumn{2}{|c|}{$\begin{array}{c}\text { Heavyweight } \\
\text { Concrete }\end{array}$}} \\
\hline & & & \multicolumn{2}{|c|}{ Alumunium foil } & \multicolumn{2}{|c|}{ Alumunium foil } & & & & \\
\hline Cost & 100 & & 8 & 800 & 7 & 700 & 4 & 400 & 9 & 900 \\
\hline Insulation & 90 & & 6 & 540 & 7 & 630 & 9 & 810 & 4 & 360 \\
\hline HRE cost based & 80 & & 9 & 720 & 8 & 640 & 7 & 560 & 5 & 400 \\
\hline $\begin{array}{l}\text { HRE material } \\
\text { based }\end{array}$ & 70 & & 7 & 490 & 8 & 560 & 9 & 630 & 6 & 420 \\
\hline $\begin{array}{l}\text { Complexity of } \\
\text { work }\end{array}$ & 60 & & 7 & 420 & 6 & 360 & 8 & 480 & 9 & 540 \\
\hline & Score & & (I) & 2970 & (II) & 2890 & (III) & 2880 & (IV) & 2620 \\
\hline
\end{tabular}

In general, the decision of the best chosen material is described and inferred in Table 7 . Here, the criteria of selection are based on cost, insulation performance, Heat Resistance Effectiveness (HRE) based on cost and material, and also the complexity of work. The criteria then scored based on urgency and its relation with the cost and effectiveness to use each material as alternatives. Each criterion becomes the comparison basis among alternatives. From its total score, it shows that the construction's schedule number 2 as preferably choice if the heavyweight concrete is covered inside with the addition layer of glass wool and aluminum foil. Overall, roof insulation has a significant effect on energy utilization, due to external heat gain through the envelope and roof, so the cooling unit is needed by the owner to meet their desired temperature. Thus, it also means that the material layer in the envelope building must be an important concern for building planners. However, indoor air quality could affect satisfaction of occupants, linearly correlated with Indonesia's aim to supply affordable and decent housing for low-middle income society.

\section{Acknowledgement}

This research / article's publication is supported by Mr. Tri Sunaryanto as Project Quantity Surveyor for helping in making Bill of Quantity and Price Analysis.

\section{References}

1) PERUMNAS Official Website, view at http://www.perumnas.co.id/program-sejuta-rumahmerupakan-bagian-dari-nawacita/ accessed on : July 17th, 2018.

2) PERUMNAS Official Website, view at http://www.perumnas.co.id/peremajaan-rusunsukaramai-medan-resmi-dilakukan/ accessed on : July 17th, 2018.

3) Huang, Xiaodan. Ma, Xiaoli. Zhang, Qingyuan. "Effect of Building Interface Form on thermal comfort in gymnasiums in hot and humid climate." Frontiers of Architectural Research, in Press (2019)
4) Zingre, K. T., et al. "Modeling of Cool Roof Heat Transfer in Tropical Climate". Renewable Energy 75, Page 210-223 (2015).

5) Zhang, J. "A Study on Thermal Processes of Traditional Dwellings - Xi'an". Xi an University of Architecture and Technology (2006)

6) Pisello, Anna Laura. Castaldo, Veronica Lucia, Piselli. Pignatta, Gloria. Cotana, Franco. "Combined Thermal Effect of Cool Roof and Cool Façade on Prototype Building". Energy Procedia 78, Page 1556-1561 (2015)

7) Ran, J. Tang, M. "Effect of Building Roof Insulation Measures on Indoor Cooling and Energy Saving in Rural Areas in Chongqing". Science Direct, Procedia Engineering 180, page 669 - 675, (2017).

8) Halwatura, R.U. Jayasinghe, M.T.R. "Influence of Insulated Roof Slabs on Air Conditioned Spaces in Tropical Climatic Conditions". Energy and Buildings 41, Page 678-686 (2009).

9) Zingre, Kishor T. Yang, Xingguo. Wan, Man Pun. "Performance Analysis of Cool Roof, Green Roof and Thermal Insulation on a Concrete Flat Roof in Tropical Climate". EVERGREEN - Joint Journal of Novel Carbon Resource Sciences \& Green Asia Strategy 2 (2), Page 34-43 (2015)

10) Koloktroni, Maria. et al. "Cool Roofs : High Tech Low Cost Solution for Energy Efficiency and Thermal Comfort in Low Rise Low Income Houses in High Solar Radiation Countries". Energy and Buildings 176, Page 58-70 (2018)

11) Halwatura, R.U. Jayashinghe, M.T.R. "Thermal Performance of Insulated Roof Slabs in Tropical Climate". Energy and Buildings 40, Page 1153-1160 (2008).

12) Hui, S.C. "Overall Thermal Transfer Value (OTTV): How to Improve Its Control in Hongkong". In Procedia of the One-Day Symposium on Building, Energy and Environment. (1997) 
13) Yao, R., B. Li, And K. Steemers. "Energy Policy and Standard for Built Environment in China". Renewable Energy 30(13), Page 1973-1988 (2005)

14) Tong, Shanshan. Zhang, Zhijun. Yu, Haibo. "Life Cycle Analysis of Cool Roof in Tropical Areas". Procedia Engineering 169, Page 392 - 399 (2016).

15) New, Joshua. Miller, Wiliam.A. Huang, Yu. Levinson, Ronnen. "Comparison of Software Models for Energy Savings from Cool Roofs". Energy and Buildings 114, Page 130-135 (2016)

16) Zhingre, K.T., et al. "Modeling of Cool Roof Heat Transfer in Tropical Climate". Renewable Energy 75, Page 210-223 (2015)

17) Garg, Vishal., et al. "Assesment of the Impact of Cool Roofs in Rural Buildings in India". Energy and Building 114, Page 156-163 (2016).

18) Neogi, Subhasis. Chowdhury, Debashish. Ganguly, Arna. "Performance of Building Roofs on Energy Efficiency- A Review”. Energy Procedia 90, Page 200-208 (2016).

19) Jóhannesson, Gudni A. Building Physics. TERC KFT, Budapest (2013).

20) Indonesia National Standardization Agency (BSN). "Standard of Energy Conservation on Building Envelope". Code of Indonesia National Standard (SNI):; no. 6389 (2011).

21) Budaiwi, I. Abdou, Adel. "Comparison of Thermal Conductivity Measurements of Building Insulation Materials under Various Operating Temperature". Journal of Building Physics. 29, No.2, Page 171 (2005).

22) Jarfelt, U. Ramnas, O. "Thermal conductivity of Polyurethane Foam - Best Performance". 10 International Symposium on District Cooling \& Heating - Chalmers University of Technology. (September 3-5 ${ }^{\text {th }}, 2006$ ).

23) Kim, M.I. "Mechanical and Thermal Properties of Epoxy Composites Containing Zirconium Oxide Impregnated Halloysite Nanotubes". Coatings 7(12), Page 231 (2007).

24) Department of Energy, USA. Engineering Reference, EnergyPlus Software Documentation V8.40.

25) American Society of Heating, Refrigeration and Airconditioning Engineer. Standard No. 55 (2013).

26) Hwataik Han, Sholahudin, Azimil Alam, Chang-In Baek. "Prediction and Analysis of Building Energy Efficiency Using Artificial Neural Network and Design of Experiments". Applied Mechanics and Materials. 819, Chapter 8, Page 541-545 (2015). 